\title{
Morning Glory Syndrome Associated with Posterior Lenticonus
}

\author{
Xiao-Guang Cao*, Xiao-Xin Li and Yong-Zhen Bao
}

Department of Ophthalmology, People's Hospital of Peking University, Beijing 100044, P.R. China

\begin{abstract}
The clinical features of the morning glory syndrome (MSG) are demonstrated in a 12-year-old male patient with the posterior lenticonus in the left eye. This patient had retinal detachment in the left eye. A complete ocular examination was performed and the patient underwent a pars plana vitrectomy of the left eye. Slit-lamp examination revealed the posterior lenticonus with the posterior subcapsular opacities in the left eye. The fundus showed the symptoms of MGS. The discs were pink and deeply excavated, surrounded by a ring of chorioretinal pigmentary disturbance. The retina has remained reattached for six months after surgery. Although most cases of MGS present with retinal and vitrea abnormalities, it may also occur in association with the lens anomalies, including the posterior lenticonus and subcapsular cataract. This association may be helpful to explore the pathogenesis of MGS.
\end{abstract}

Keywords: Morning glory syndrome, posterior lenticonus.

\section{INTRODUCTION}

Morning Glory Syndrome (MGS) is a rare condition. The morning glory optic disc anomaly was first reported in the German literature in 1929 but had been more frequently reported since its description by Kindler [1]. The anomaly was termed 'morning glory syndrome' because of its resemblance to the tropical flower. The disc is usually enlarged with a funnel-shaped excavation surrounded by a usually raised pigmentary border. Whitish glial tissue is present at the bottom of the disc, representing an important criterion for diagnosing the syndrome [2]. The retinal blood vessels emerge from the periphery of the excavation in a radial pattern. Posterior lenticonus or lentiglobus is a wellcircumscribed, round or oval protuberance of the posterior lens capsule that is restricted to a 2.0 to $7.0 \mathrm{~mm}$ axial area [3]. It is not associated with systemic disease and may be diagnosed in infancy, and the posterior bulge may increase with age $[4,5]$. Complicated cataract is often associated with this anomaly, although severe distortion through a clear lens alone may be an indication for surgical intervention. We describe a case of morning glory syndrome associated with posterior lenticonus.

\section{MATERIALS AND METHODS}

A 12-year-old Chinese boy was evaluated by routine ophthalmologic examinations, including visual acuity test for the best corrected visual acuity, Godmann applanation tonometry for intraocular pressure; slit-lamp biomicroscopic examination for anterior segment; distant direct ophthalmoscopy for lens abnormality; and binocular indirect ophthalmoscopy for fundus

\section{Case}

A 12-year-old boy presented with a 2-month history of the retinal detachment in his left eye. He had a failed sclera

\footnotetext{
*Address correspondence to this author at the Department of Ophthalmology, People's Hospital of Peking University, Beijing 100044, P.R. China; Tel: 8613681053297; Fax: 861068792813; E-mail: cxgcat@hotmail.com
}

buckling at two months of age. We had no access to his previous medical records and are unaware of his prior visual acuity. The patient did not have hearing problems and systemic examination was unremarkable. There was no auditory symptom, and audiometry was normal.

Ocular evaluation revealed the best corrected visual acuity of 20/20 in the right eye and 1/50 in the left eye. Intraocular pressure was $18 \mathrm{mmHg}$ in the right eye and $10 \mathrm{mmHg}$ in the left eye. Slit-lamp biomicroscopic examination revealed a subtle but definite posterior oval protuberance and posterior lenticonus with posterior subcapsular opacities in the left eye (Fig. 1). Distant direct ophthalmoscopy showed an oil droplet reflex in the left eye. There was a large excavated disc with retinal vessels radiating from the periphery a tuft of translucent fibrous tissue covering the central part of excavation (Fig. 2), and peripapillary chorioretinal pigmentary change. The macular area with its xanthophyll pigment was displaced to the temporal margin of the excavation. The patient was diagnosed with the morning glory syndrome with posterior lenticonus.

The patient underwent pars plana vitrectomy of the left eye with the removal of the posterior hyaloid, fluid-air exchange, endolaser to the margin of the excavated disk, and injection of silicone oil. Retinal detachment recurred 2 months after the silicone oil was taken out. Repeated surgery with additional endolaser surrounding the optic nerve anomaly and injection of silicone oil resulted in retinal reattachment. During a 6-month follow-up, the visual acuity was $1 / 40$, and the retina remained attached.

\section{DISCUSSION}

Morning glory syndrome frequently occurs as an isolated ocular abnormality, but systemic associations have been reported, including midline craniofacial defects $[2,6]$, defects of the sella turcica and endocrine dysfunction [6], Charge syndrome [7], moyamoya disease [8] and neurofibromatosis type $2[9]$. 

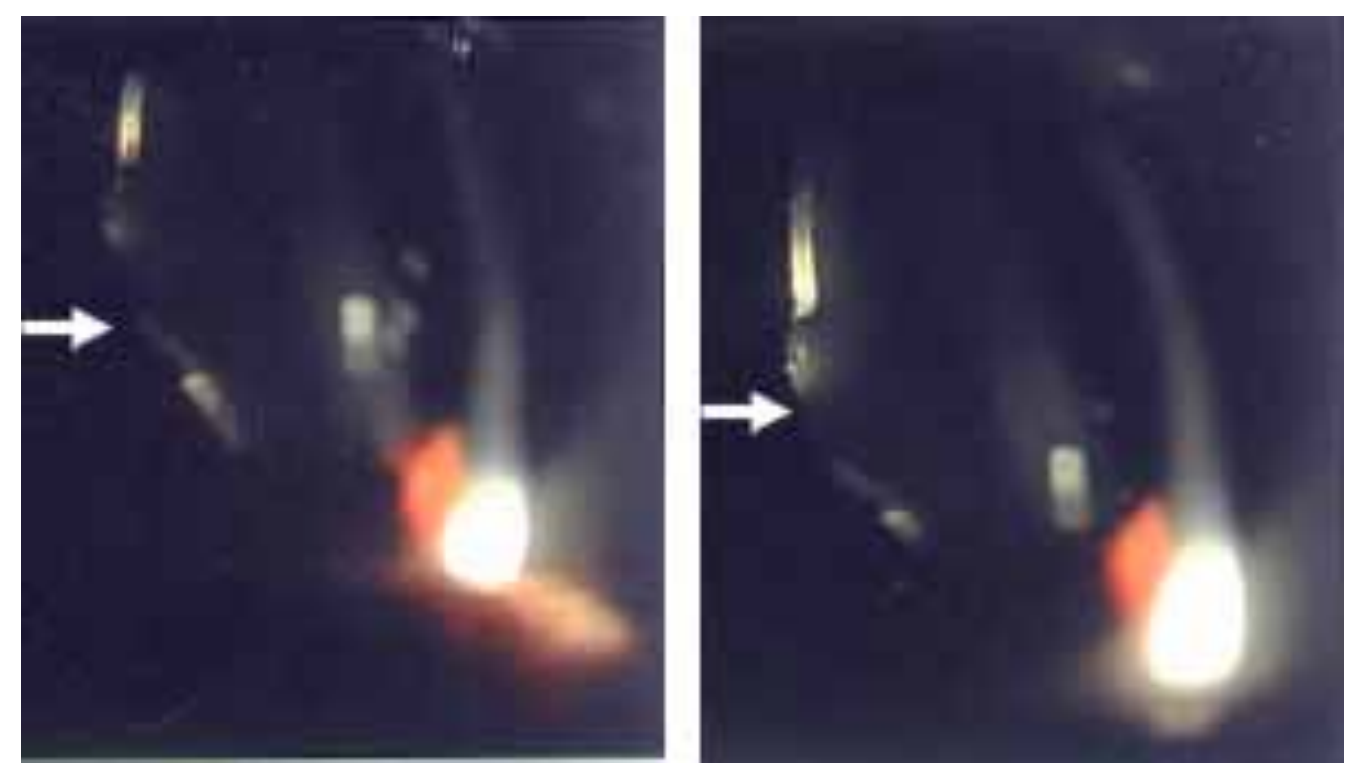

Fig. (1). The posterior lenticonus photograph of the left eye. The slit beam on the posterior lens surface is more curved than usual (arrow).

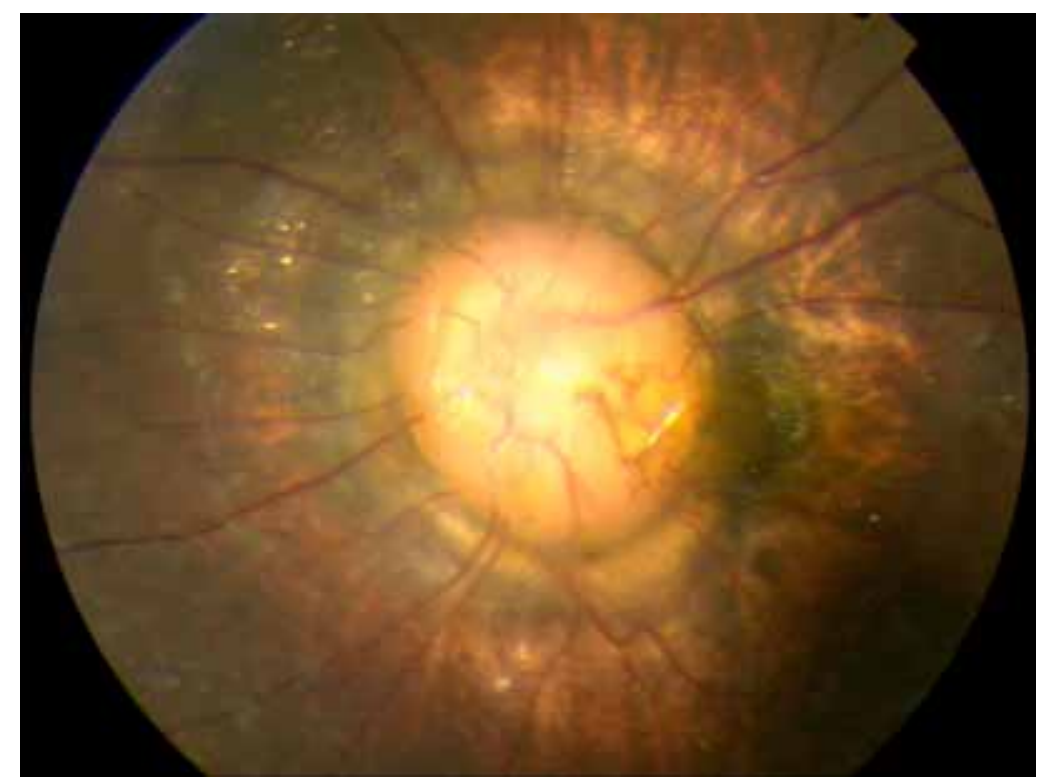

Fig. (2). The post-operative funduscopic photograph of the left eye. The optic disc is enlarged and excavated. A tuft of whitish tissue is present in the centre of the disc. There are peripapillary pigmentary changes and the retinal vessels emerge from under the central tissue and run a straight course toward the periphery of the retina.

Ocular associations found in affected eyes with morning glory disc anomaly may include retinal detachment, congenital cataract, persistent hyaloid remnants, lid haemangioma and preretinal gliosis [1]. Retinal detachment is the most common ocular complication. . The posterior lenticonus had not been reported in the previous studies in associaton with MGS.

Posterior lenticonus is a rare condition first described by Meyer in 1888 [10]. Most cases are unilateral and sporadic, and there is little published evidence that it is a familial condition. In contrast, bilateral posterior lenticonus is more likely to be inherited and the gene responsible may be located on the X chromosome [11]. Posterior lenticonus is usually detected between 3 and 15 years of age [12].
The pathogenesis of posterior lenticonus remains obscure. Khalil and Saheb [13] report ed that posterior lenticonus is most likely caused by herniation of cortical lens fibers and posterior capsule into the vitreous at an area of posterior capsule weakness during fetal development. Franceschetti and Rickli [14] postulated that the anomaly is an aberrant hyperplasia of the subcapsular epithelium overlying the cone. Mann [15] speculated that a disturbance in the tunica vasculosa lentis accounts for the anomaly. Hess [16] suggests that lenticonus occurs due to a rupture of the posterior lens capsule resulting from hyaloid artery traction, as was observed in the pig and rabbit. Trauma has also been reported to cause a lenticonus-like defect [17]. 
The nature of the embryological defect leading to the morning glory disc anomaly is also widely disputed [18]. The developmental interruption most likely occurs at the four to five weeks stage of embryonic growth [19]. Pedler [20] considered the defect secondary to faulty closure of the posterior sclera and herneation of the optic disc and Jacobs and Taylor [21] supported this view. Traboulsi [22] claimed that failure of normal neuroectodermal development might play a role in the disc anomaly.

As the lens rises from ecderon-ectoderm, the retina, the neurocyte and neurofibra of the optic nerve rise from neuroectoderm. We suggest that the hyaloid artery or/and primary vitreous traction might be associated with MGS and the posterior lenticonus of the patient. Moreover, since the patient had no trauma and history of intraocular surgery, injury from surgery could be excluded.

\section{CONCLUSION}

Although the retinal and vitreal abnormities were commonly found in patients with optic nerve hypoplasia, to our knowledge, the association of morning glory syndrome with the posterior pituitary lenticonus has not been previously described. This case reinforces the importance of early recognition and treatment of lens anomalies in patients with MGS and provides a clue for the study of MGS.

\section{REFERENCES}

[1] Kindler P. Morning glory syndrome: unusual congenital optic disk anomaly. Am J Ophthalmol 1970; 69(3): 376-84.

[2] Leitch RJ, Winter RM. Midline craniofacial defects and morning glory disc anomaly: a distinct clinical entity. Acta Ophthalmol Scand Suppl 1996; 219: 16-9.

[3] Gibbs ML, Jacobs M, Wilkie AO, Taylor D. Posterior lenticonus: clinical patterns and genetics. J Pediatr Ophthalmol Strabismus 1993; 30(3): 171-5.

[4] Colville DJ, Savige J. Alport syndrome: a review of the ocular manifestations. Ophthalmic Genet 1997; 18(4): 161-73.
[5] Jacobs K, Meire FM. Lenticonus. Bull Soc Belge Ophtalmol 2000; 277: 65-70.

[6] Eustis HS, Sanders MR, Zimmerman T. Morning glory syndrome in children: association with endocrine and central nervous system anomalies. Arch Ophthalmol 1994; 112(2): 204-7.

[7] Risse JF, Guillaume JB, Boissonnot M, Bonneau D. An unusual polymalformation syndrome: "CHARGE association" with unilateral "morning glory syndrome". Ophtalmologie 1989; 3(3): 196-8.

[8] Massaro M, Thorarensen O, Liu GT, Maguire AM, Zimmerman RA, Brodsky MC. Morning glory disc anomaly and moyamoya vessels. Arch Ophthalmol 1998; 116(2): 253-4.

[9] Brodsky MC, Landau K, Wilson RS, Boltshauser E. Morning glory disc anomaly in neurofibromatosis type 2. Arch Ophthalmol 1999 117(6): 839-41.

[10] Meyer F. Ein fall von lenticonus posterior. Centralbl Prakt Augenheilkd 1888; $12: 6$

[11] Vivian AJ, Lloyd C, Russell-Eggitt I, Taylor D. Familial posterior lenticonus. Eye 1995; 9 ( Pt 1): 119-23.

[12] Crouch ER, Jr, Parks MM. Management of posterior lenticonus complicated by unilateral cataract. Am J Ophthalmol 1978; 85(4): 503-8.

[13] Khalil M, Saheb N. Posterior lenticonus. Ophthalmology 1984; 91(11): 1429-30, 43A.

[14] Franceschetti A, Rickli H. Posterior (eccentric) lenticonus: report of first case with clinical and histological findings. AMA Arch Ophthalmol 1954; 51(4): 499-508.

[15] Mann I. Developmental abnormalities of the eye. Philadelphia: JB Lippincott 1957.

[16] Hess C. excentrische bildung des linsenkernes und die histologie des lenticonus posterior. Deutschen Ophthalmologischen Gesellschaft 1986; $25: 301$

[17] Tipshus A. Posterior traumatic cataract. Arch Ophthalmol 1969; 82: 2.

[18] Brodsky MC. Congenital optic disk anomalies. Surv Ophthalmol 1994; 39(2): 89-112.

[19] Debney S, Vingrys AJ. Case report: the morning glory syndrome. Clin Exp Optom 1990; 73: 5.

[20] Pedler C. Unusual coloboma of the optic nerve entrance. Br J Ophthalmol 1961; 45(12): 803-7.

[21] Jacobs M, Taylor D. The systemic and genetic significance of congenital optic disc anomalies. Eye 1991; 5 ( Pt 4): 470-5.

[22] Traboulsi EI, Jurdi-Nuwayhid F, Torbey NS, Frangieh GT. Aniridia, atypical iris defects, optic pit and the morning glory disc anomaly in a family. Ophthalmic Paediatr Genet 1986; 7(2): 131-5.

Received: December 12, 2008

Revised: April 24, 2009

Accepted: May 01, 2009

(C) Cao et al.; Licensee Bentham Open.

This is an open access article licensed under the terms of the Creative Commons Attribution Non-Commercial License (http://creativecommons.org/licenses/by-nc/3.0/) which permits unrestricted, non-commercial use, distribution and reproduction in any medium, provided the work is properly cited. 